\title{
Physico-Chemical and Microbiological Profile of Effluents from Common Effluent Treatment Plants (CETPs)
}

\author{
Gaganpreet Kaur, Priya Katyal ${ }^{*}$ and Dhanwinder Singh
}

\author{
Department of Microbiology, Punjab Agricultural University, Ludhiana, Punjab, India \\ *Corresponding author
}

\begin{tabular}{|l|}
\hline Ke y w o r d s \\
Common Effluent \\
$\begin{array}{l}\text { Treatment Plants, } \\
\text { bioremediation, } \\
\text { heavy metal } \\
\text { tolerant, ICAP- } \\
\text { AES. }\end{array}$ \\
\hline Article Info \\
\hline $\begin{array}{l}\text { Accepted: } \\
\text { 19 July } 2017 \\
\text { Available Online: } \\
\text { 10 September } 2017\end{array}$ \\
\hline
\end{tabular}

\section{Introduction}

Due to rapid industrial progress and urbanization, environmental pollution with toxic heavy metals has become one of the major concerns in today's world (Kinare and Shingadia 2014). Environmental pollution due to chemicals and heavy metals is spreading throughout the world and is a problem that may have negative consequences on the hydrosphere. Metal contaminated aquifers pose serious threat to health and ecosystems.
Copper, chromium, cadmium and nickel are known to be the most commonly used heavy metals and are the more widespread contaminants of the environment (Aksu 1998, Doenmez and Aksu 1999). Some heavy metals are essential in trace amount, but high levels of them may cause extreme toxicity to living organisms due to inhibition of metabolic reactions. These are considered to be more persistent and stable than organic 
contaminants such as pesticides or petroleum by-products and are non-biodegradable (Lasat 2002, Kavamura and Esposito 2010). Their presence in soils and water can be from natural (Ernst 1998) or anthropogenic origins (Alloway 1995).

Removal of excesses of heavy metal ions from wastewaters is essential due to their extreme toxicity towards aquatic life and humans. These metals can become mobile in soils depending on soil $\mathrm{pH}$ and their speciation and finally a fraction of the total mass can leach to aquifer or can become bioavailable to living organisms (Santona et al., 2006, Khan et al., 2008). Heavy metals can accumulate in biological systems and ultimately be introduced into food web via different mechanisms (Giller et al., 1998).

It is well known that heavy metals can be extremely toxic as they damage nerves, liver and bones, and also block functional groups of vital enzymes (Moore 1990, Ewan and Pamphlett 1996). Heavy metal contamination thus considered a serious threat to both the ecosystem and human and requires expensive clean-up costs. Inhibitory effect of heavy metals is a common phenomenon that occurs in the biological treatment of waste water and sewage (Filali et al., 2000, Kongtae et al., 2013).

The bioremediation of heavy metals using microorganisms has received a great deal of attention in recent years, not only as a scientific novelty but also for its potential application in industry. Though the applications of genetically engineered microorganisms (GEMs) in bioremediation have received a great deal of attention, As GEMs have higher degradative capacity and have been demonstrated successfully for the degradation of various pollutants under defined conditions. However, ecological/environmental concerns and regulatory constraints are major obstacles for testing GEMs (Menn et al., 2008).

Punjab is a hub of small and medium-scale industries. For minimizing environmental pollution by these industries a cleaner production technology and waste minimization has to be reinforced. A collective treatment of this waste at a centralized facility known as Common Effluent Treatment Plants (CETPs) can go a long way in minimizing the constraints associated with effluent treatment in small to medium enterprises. Till 1990, only one CETP at Jeedimetla, Hyderabad was in operation. But in 1991, Ministry of Environment and Forests (MoEF), GoI initiated an innovative financial support scheme for CETPs to ensure the growth of the small and medium entrepreneurs (SMEs) in an environmentally compatible manner (Anonymous, 2010). The level and type of metal contaminants in the effluents collected from a CETP depend upon the type of industries it is catering for. Major sources of chromium pollution include effluents from leather tanning, chromium electroplating, wood preservation, alloy preparation and nuclear wastes (Thacker et al., 2006). The CETPs selected in this study include the one dealing with electroplating industry waste and other with the tannery effluents.

Metal remediation in these CETPs involve the use of conventional technologies, such as ion exchange, chemical precipitation, reverse osmosis and evaporative recovery which are often inefficient or very expensive (Volesky 1990). Compared with the above methods the removal of heavy metals with indigenous microorganisms has advantages such as low cost and without secondary pollution (Jun-xia et al., 2007) and biosorption is an ideal candidate for the treatment of high volume and low concentration complex wastewaters (Wang and Chen 2006). There is a need for 
innovative treatment technologies for the removal of heavy metal ions from wastewater. Different microbes have been proposed to be efficient and economic alternative in removal of heavy metals from water (Waisberg et al., 2003). Bioremediation can be used to effectively reduce contaminant toxicity, mobility or volume to levels that are innocuous to human health and ecosystem (Toroglu and Dincer 2009).

Studies on bacterial diversity in heavy metal contaminated sites have demonstrated the presence of a variety of strains (Ellis et al., 2003). These indigenous organisms have not only adapted to the new environments but have also flourished under them (Haq and Shakoori 2000, Roane and Pepper 2000). So exploiting these organisms can be advantageous over the introduction of some foreign/alien microbial culture. The survival of the newly introduced bacterial species under the conditions existing at contaminated sites may be doubtful while intrinsic flora or resident microbes can be far well acclimatized and can have better survival rate and faster growth. Application of a judicious consortium of growing metal-resistant cells can ensure better removal through a combination of bioprecipitation, biosorption and continuous metabolic uptake of metals after physical adsorption.

Recent studies have shown that the strains (bacteria, yeast and fungi) isolated from contaminated sites possesses excellent capability of metal scavenging. The multiple metal resistance is often correlated with antibiotic resistance. Some bacterial strains, possessing high tolerance to various metals and antibiotic, may be the potential candidates for metal clean-up from wastes. This work mainly focuses on the isolation of heavy metal resistant strains of bacteria for their applicability in treatment of metal-rich effluents.

\section{Study area}

Samples were collected from Ludhiana Electroplaters Association CETP, Focal Point, Ludhiana and Punjab Small Industries and Export Cooperation (PSIEC), Leather Complex CETP, Kapoorthala road, Jalandhar, Punjab. Samples were collected in sterile plastic container.

\section{Materials and Methods}

\section{Analysis of physico-chemical parameters}

The collected samples were analyzed for normal physico-chemical parameters such as $\mathrm{pH}$, dissolved oxygen (DO), biological oxygen demand (BOD) and chemical oxygen demand (COD) within 12 hours of collection using standard methods (APHA 2001). For determination of $\mathrm{pH}$ of the samples a $\mathrm{pH}$ meter (S.D. fine-chem limited) was used.

\section{Heavy metal profile of effluent}

The concentration of heavy metals such as arsenic, chromium, mercury, nickel, lead etc. present in both the effluent samples was estimated using Inductively Coupled Argon Plasma-Atomic Emission Spectroscopy (ICAP-AES) (Thompson and Walsh 1989).

\section{Isolation and maintenance of bacterial isolates}

Isolation of indigenous metal resistant bacteria was carried out using standard microbiological techniques by which Luria Bertani Agar plates supplemented with $5 \mathrm{mg} / \mathrm{l}$ concentration of six different heavy metals i.e. $\mathrm{As}, \mathrm{Cr}, \mathrm{Hg}, \mathrm{Ni}, \mathrm{Pb}$ and $\mathrm{W}$ were used. The plates were incubated at $37^{\circ} \mathrm{C}$ for 3-5 days. Individual bacterial colonies on LB agar plates which varied in shape and color were picked up and purified by repeated subculturing on the same medium. Pure 
cultures of bacterial colonies were preserved at $4^{\circ} \mathrm{C}$ as slant cultures for further analysis.

\section{Determination of Minimum Inhibitory Concentration (MIC) of different selected heavy metals}

Maximum resistance of the isolates to six heavy metals ( $\mathrm{As}, \mathrm{Cr}, \mathrm{Hg}, \mathrm{Pb}, \mathrm{Ni}$ and $\mathrm{W}$ ) was evaluated in LB agar plates amended with each heavy metal in concentration ranging from $5 \mathrm{ppm}$ to $100 \mathrm{ppm}$.

The concentration of respective heavy metal was raised in agar plate until the strain failed to grow on the plate. The plates were incubated at $37^{\circ} \mathrm{C}$ for $24-48 \mathrm{~h}$ and bacterial growth was observed to evaluate MIC.

\section{Biochemical characterization of selected bacterial isolates}

Biochemical characterization of bacterial isolates was done on the basis of oxidase, catalase, VP-test, MR-VP test, starch hydrolysis and gelatin hydrolysis, indole production and citrate utilization as per Bergey's Manual of Systematic Bacteriology (Claus and Berkeley 1986).

\section{Optimization of growth parameters for selected isolates}

\section{Effect of $\mathrm{pH}$ on the growth of selected} isolates

Optimization of the growth of the four selected isolates (HM 2, HM 4, HM 15 and $\mathrm{HM}$ 16) with reference to $\mathrm{pH}$ was done. For each of these bacterial strains, $250 \mathrm{ml}$ flasks containing $50 \mathrm{ml}$ of Luria Bertani broth were adjusted at different $\mathrm{pH}$ values i.e. 6, 7, 8, 9 and 10 and autoclaved at $120^{\circ} \mathrm{C}$ for $20 \mathrm{~min}$. After autoclaving, the broth was inoculated with $0.5 \mathrm{ml}$ of $12 \mathrm{~h}$ old culture of selected isolates. The optical density of log phase growing cultures (8-10h old) was measured at $540 \mathrm{~nm}$.

Effect of temperature on the growth of selected isolates

Optimization of the growth of the four selected isolates (HM 2, HM 4, HM 15 and 16) with reference to temperature was done. For each of these bacterial strains, $250 \mathrm{ml}$ flasks containing $50 \mathrm{ml}$ of Luria Bertani broth were autoclaved at $120^{\circ} \mathrm{C}$ for $20 \mathrm{~min}$. After autoclaving, the flasks were inoculated with $0.5 \mathrm{ml}$ of $12 \mathrm{~h}$ old culture of selected isolates and incubated at different temperatures i.e. $25^{\circ} \mathrm{C}, 30^{\circ} \mathrm{C}, 35^{\circ} \mathrm{C}, 45^{\circ} \mathrm{C}$ and $50^{\circ} \mathrm{C}$. The optical density of log phase growing cultures (8-10h old) was measured at $540 \mathrm{~nm}$.

\section{Results and Discussion}

In Punjab, a total of six CETPs are located (Table 1). Out of six CETPs, only two were working and samples were collected from these two CETPS i.e. Ludhiana Electroplaters Association CETP, Ludhiana and Punjab Small Industries and Export Corporation (PSIEC) Leather complex CETP, Jalandhar. Samples inoculated in media supplemented with $5 \mathrm{mg} / \mathrm{l}$ of different heavy metals led to the isolation of total of 21 isolates, out of which only 10 were found to be morphologically distinct from each other.

\section{Physico-chemical characterization of effluent samples collected from common effluent treatment plants CETP}

Results revealed that sample 1 was found to be highly acidic ( $\mathrm{pH}=2.5)$ because this CETP caters the need of electroplating industries, whereas sample 2 was alkaline $(\mathrm{pH}=9.0)$ because it caters the need of tannery industry (Table 2). The BOD of sample 1 (17.2 mg/l) was less as compared to sample $2(69.8 \mathrm{mg} / \mathrm{l})$, but the COD of sample $1(390 \mathrm{mg} / \mathrm{l})$ was 
more as compared to sample $2(372 \mathrm{mg} / \mathrm{l})$, these results revealed that the sample 2 was rich in organic matter content with lesser load of heavy metal contents. Earlier also Alam et al., (2011) also reported a high BOD of the tannery effluent irrigated soil and the level of organic matter of tannery effluent irrigated soil was found higher than the control soil. Kamika and Momba (2013) reported that the average value of COD of industrial wastewater effluent was higher than $100 \mathrm{mg} / \mathrm{l}$ and the value of DO between 5.76 to 6.81 $\mathrm{mg} / \mathrm{l}$.

\section{Comparative heavy metal profile of effluents from CETPs}

The heavy metal profile of both the effluent samples was determined by using Inductively Coupled Argon Plasma-Emission Spectroscopy (ICAP) analysis. Whereby, $\mathrm{Cr}$ was found to be the dominant metal contaminant with a concentration of $238 \mathrm{ppm}$, followed by nickel-92 ppm, lead-18.5 ppm, cadmium-0.3 ppm, arsenic-0.04 ppm in sample 1. Similarly, in sample 2 concentration of $\mathrm{Cr}$ was $23.20 \mathrm{ppm}$ followed by $\mathrm{Pb}(20.61 \mathrm{ppm})$ and $\mathrm{Ni}(6.65 \mathrm{ppm})$. Level of heavy metal contaminants in sample 1 was higher in comparison to sample 2 and was above permissible limits in both the samples.
The concentration of $\mathrm{Cr}$ was 2380 times higher than the permissible limit $(0.1 \mathrm{ppm})$ in sample 1. This is in accordance with the earlier study by Verma et al., (2001), who analysed tannery effluents for the content of the various heavy metals and found that the total chromium (28.96 ppm) and nickel concentrations $(1.08 \mathrm{ppm})$ in the effluent exceeds the permissible limits (Table 3 ).

\section{Morphological characterization of isolated strains}

A total of 21 strains were isolated, 10 were found to be Gram -ve and 11 were Gram +ve. These isolates were morphologically characterized, 10 isolates HM 1, HM 2, HM 3, HM 5, HM 8, HM 9, HM 12, HM 14, HM 15 and HM 16 were found to be morphologically distinct. These 10 isolates were selected for determination of Minimum Inhibitory Concentration (MIC) against six different heavy metals i.e. As, $\mathrm{Hg}, \mathrm{Ni}, \mathrm{W}, \mathrm{Pb}$ and $\mathrm{Cr}$. Table 4 revealed the colony morphology and the Gram's character. Several investigators have reported high level of metal resistance in bacteria isolated from wastewater. Shakoori and Muneer (2002) isolated bacteria from wastewater and found that all isolates were resistant to $\mathrm{Cr}, \mathrm{Cd}, \mathrm{Hg}$ and $\mathrm{Zn}$.

Table.1 Location and address of common effluent treatment plants (CETPs) located in Punjab

\begin{tabular}{|l|l|l|l|}
\hline S.No. & Name & Address & Remarks \\
\hline 1. & $\begin{array}{l}\text { Punjab Small Industries and Export } \\
\text { Corporation (PSIEC) Leather Complex } \\
\text { CETP }\end{array}$ & $\begin{array}{l}\text { Kapoorthala Road. Jalandhar, } \\
\text { Punjab }\end{array}$ & $\begin{array}{l}\text { Currently under stabilization as } \\
\text { it was closed for over 2 years }\end{array}$ \\
\hline 2. & Malerkotla Electroplating Association CETP & $\begin{array}{l}\text { Malerkotla, Distt. Sangrur, } \\
\text { Punjab }\end{array}$ & Yet not working \\
\hline 3. & Ludhiana Electroplaters Association CETP & $\begin{array}{l}\text { D-260-261, Focal Point } \\
\text { Phase-8, Ludhiana } \\
\text { Ramdaspura Noormahal } \\
\text { Road, Phillore, Distt. } \\
\text { Jalandhar, Punjab }\end{array}$ & $\begin{array}{l}\text { Capacity to cater to nearly } 900 \\
\text { units }\end{array}$ \\
\hline 4. & Dr. Ambedkar Leather Association CETP & Tajpur Road, Ludhiana & $\begin{array}{l}\text { Work was stalled due to a very } \\
\text { high project cost }\end{array}$ \\
\hline 5. & Textile units CETP & Bahdurke Road, Ludhiana & $\begin{array}{l}\text { CETP Project was delayed and } \\
\text { not yet started }\end{array}$ \\
\hline 6. & Textile units CETP & \multicolumn{2}{|l}{} \\
\hline
\end{tabular}


Table.2 Comparative physico-chemical parameters of effluent samples collected from CETPs

\begin{tabular}{|l|l|l|l|l|}
\hline \multicolumn{1}{|c|}{ Sample no. and location } & \multicolumn{1}{c|}{$\mathrm{pH}$} & $\mathrm{DO} \mathrm{mg} / \mathrm{l}$ & $\mathrm{BOD} \mathrm{mg} / \mathrm{l}$ & $\mathrm{COD} \mathrm{mg} / \mathrm{l}$ \\
\hline $1 . \quad$ Ludhiana Electroplaters Association CETP & $2.5 \pm 0.3$ & $47.8 \pm 0.5$ & $17.2 \pm 0.2$ & $390 \pm 0.4$ \\
\hline $\begin{array}{l}1 . \quad \text { Punjab Small Industries and Export } \\
\text { Corporation (PSIEC) Leather Complex CETP }\end{array}$ & $9 \pm 0.2$ & $90.3 \pm 0.3$ & $69.8 \pm 0.8$ & $372 \pm 0.5$ \\
\end{tabular}

Table.3 Comparative heavy metal profile of effluents from CETPs

\begin{tabular}{|c|c|c|c|c|}
\hline S.No & Metals & Sample no. 1 & Sample no. 2 & Permissible limit \\
\hline & & \multicolumn{2}{|c|}{ Concentration (ppm) } \\
\hline 1. & Arsenic (As) & $\mathbf{0 . 0 4}$ & N.D* & 0.2 \\
\hline 2. & Boron (B) & 24.8 & N.D & N.D \\
\hline 3. & Calcium (Ca) & 183 & N.D & N.D \\
\hline 4. & Cadmium (Cd) & $\mathbf{0 . 3 0}$ & $\mathbf{0 . 3 2}$ & $\mathbf{2 3 . 0}$ \\
\hline 5. & Chromium (Cr) & $\mathbf{2 3 8}$ & 0.0075 & 3.0 \\
\hline 6. & Copper (Cu) & 18.9 & 0.023 & 3.0 \\
\hline 7. & Iron (Fe) & 5840 & N.D & N.D \\
\hline 8. & Potassium (K) & 265 & N.D & N.D \\
\hline 9. & Magnesium (Mg) & 45 & N.D & N.D \\
\hline 10. & Sodium (Na) & 809 & $\mathbf{6 . 6 5}$ & 3.0 \\
\hline 11. & Nickel (Ni) & $\mathbf{9 2}$ & N.D & N.D \\
\hline 12. & Phosphorous (P) & 146 & $\mathbf{2 0 . 6 1}$ & $\mathbf{0 . 1}$ \\
\hline 13. & Lead (Pb) & $\mathbf{1 8 . 5}$ & N.D & N.D \\
\hline 14. & Sulphur(S) & 2538 & 0.0063 & 5.0 \\
\hline 15. & Zinc (Zn) & 266 & & \\
\hline
\end{tabular}

*Not determined

Table.4 Morphological characterization of bacterial isolates from effluent waste

\begin{tabular}{|c|c|c|}
\hline Isolate no. & Colony Morphology & Gram character \\
\hline HM 1 & Mucoid, cream & $-\mathrm{ve}$ \\
\hline HM 2 & Buttery, cream & $-\mathrm{ve}$ \\
\hline HM 3 & Sindoori & $-\mathrm{ve}$ \\
\hline HM 4 & Mucoid, off white & $-\mathrm{ve}$ \\
\hline HM 5 & Light brown, causing brownish discoloration of media & - ve \\
\hline HM 6 & Gummy, causing brownish discoloration of media & $+\mathrm{ve}$ \\
\hline HM 7 & Dirty white & $+\mathrm{ve}$ \\
\hline HM 8 & Yellowish orange & $-\mathrm{ve}$ \\
\hline HM 9 & Light orange with raised centre & $-\mathrm{ve}$ \\
\hline HM 10 & Cream & $+\mathrm{ve}$ \\
\hline HM 11 & Mucoid, light brown discoloration of media & $+\mathrm{ve}$ \\
\hline HM 12 & Dirty yellow & $+\mathrm{ve}$ \\
\hline HM 13 & Cream, irregular colonies & $+\mathrm{ve}$ \\
\hline HM 14 & Whitish & $-\mathrm{ve}$ \\
\hline HM 15 & Shinning yellow & $-\mathrm{ve}$ \\
\hline HM 16 & Lemon yellow, buttery & - ve \\
\hline HM 17 & Budding colonies with raised centre & $+\mathrm{ve}$ \\
\hline HM 18 & Creamish white & + ve \\
\hline HM 19 & Orange with metallic shine & $+\mathrm{ve}$ \\
\hline HM 20 & Peach with shine & $+\mathrm{ve}$ \\
\hline HM 21 & Orangish red with metallic shine & $+\mathrm{ve}$ \\
\hline
\end{tabular}


Table.5 Minimum inhibitory concentration (MIC) of morphologically distinct isolates

\begin{tabular}{|c|c|c|c|c|c|c|}
\hline Isolate No. & $\mathrm{Cr}$ & $\mathrm{Pb}$ & $\mathrm{As}$ & $\mathrm{Hg}$ & $\mathrm{Ni}$ & $\mathrm{W}$ \\
\hline & \multicolumn{7}{|c|}{ Concentration $(\mathrm{ppm})$} \\
\hline HM 1 & 30 & 60 & 20 & 5 & 50 & 20 \\
\hline HM 2 & $\mathbf{1 2 0}$ & $\mathbf{1 0 0}$ & $\mathbf{1 1 0}$ & - & $\mathbf{6 0}$ & $\mathbf{5 0}$ \\
\hline HM 3 & $\mathbf{1 0 0}$ & $\mathbf{9 0}$ & $\mathbf{1 0 0}$ & - & $\mathbf{4 0}$ & $\mathbf{4 0}$ \\
\hline HM 5 & 10 & - & - & - & - & - \\
\hline HM 8 & 30 & 30 & 10 & - & 30 & - \\
\hline HM 9 & 20 & 30 & 20 & - & 20 & - \\
\hline HM 12 & 70 & 60 & 30 & 10 & 30 & 15 \\
\hline HM 14 & 30 & 50 & 20 & - & - & - \\
\hline HM 15 & $\mathbf{1 1 0}$ & $\mathbf{1 0 0}$ & $\mathbf{9 0}$ & - & $\mathbf{7 0}$ & $\mathbf{3 0}$ \\
\hline HM16 & $\mathbf{1 0 0}$ & $\mathbf{1 0 0}$ & $\mathbf{8 0}$ & $\mathbf{1 0}$ & $\mathbf{9 0}$ & $\mathbf{5 0}$ \\
\hline
\end{tabular}

Table.6 Biochemical characterization of selected isolates

\begin{tabular}{|c|c|c|c|c|}
\hline Test & HM 2 & HM 3 & HM 15 & HM 16 \\
\hline Oxidase & - & - & - & + \\
\hline Catalase & + & + & + & - \\
\hline MR-test & - & - & + & - \\
\hline VP-test & + & + & + & + \\
\hline Starch hydrolysis & - & + & - & - \\
\hline Indole production & - & - & - & + \\
\hline Citrate utilization & + & + & + & - \\
\hline
\end{tabular}

Fig.1 Comparative growth profile of selected isolates at different $\mathrm{pH}$

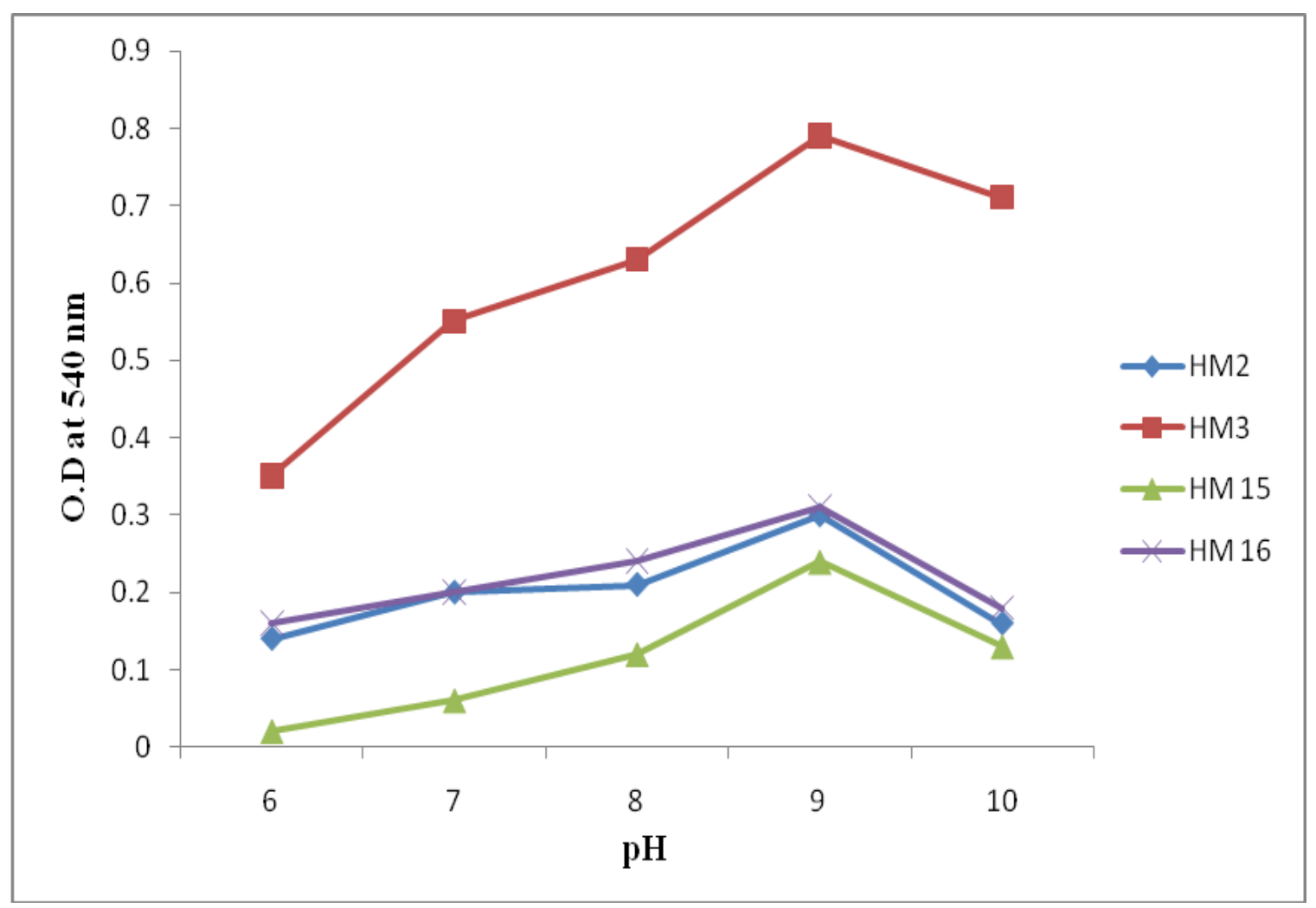


Fig.2 Comparative growth profile of selected isolates at different temperature

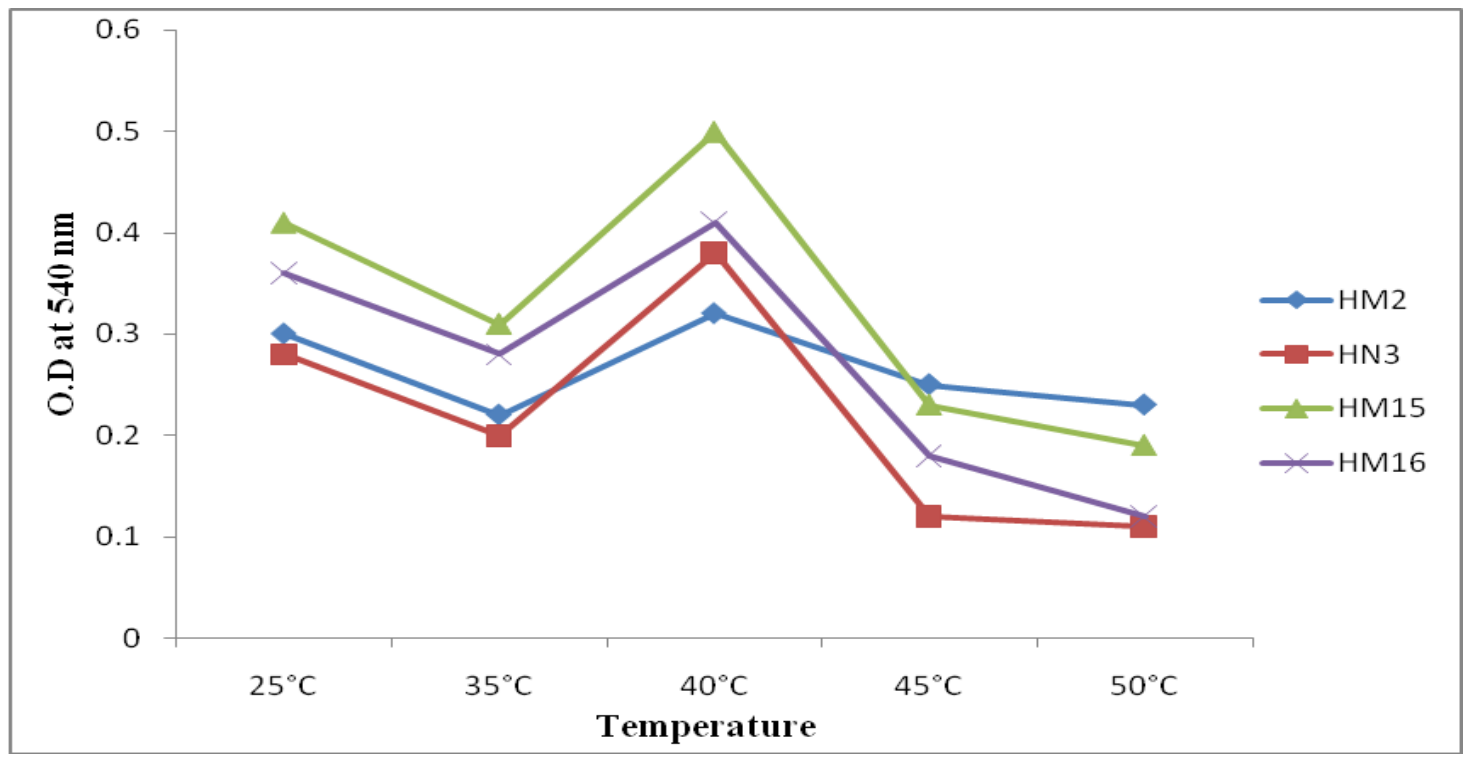

Determination of Minimum Inhibitory Concentration (MIC) of different selected heavy metals

Seven isolates HM 2, HM 3, HM 5, HM 8, HM 9, HM 14 and HM 15 were sensitive to mercury, two were sensitive to nickel HM 5 and $\mathrm{HM} 14$ and four were sensitive to tungsten HM 5, HM 8, HM 9 and HM 15. Four isolates i.e HM 2, HM 3, HM 15 and HM 16 shows maximum tolerance to five different heavy metals except mercury. These four isolates were selected for their biochemical characterization. In another study, some workers isolated 53 different species from the sediment samples collected from Krishna Godavari basin. Of these isolates, $79.24 \%$ were found to be resistant to $350 \mathrm{ppm}$ of Mercury (11.53\%), 250ppm of Cadmium (3.77\%), 700ppm of Chromate $(50.94 \%)$ and 250ppm of Zinc (13.20\%) (Gunaseelan and Ruban 2011) (Table 5).

\section{Biochemical characterization of selected isolates}

On the basis of biochemical characterization HM 3 and HM 16 were more closely related to genera Enterobacter. Whereas, HM 2 was found to belong to genera Klebsiella. Same was confirmed by their typical colony color on selective media. In a recent study, bacteria capable of accumulating heavy metals were isolated from soil samples of Mauritius and identified by standard biochemical test. Out of the 113 isolates, twelve were capable of growing in the presence of mercury, lead, silver, zinc and copper at varying concentrations (1.0-5.0mM) and were identified to belong to the Bacillales. This was confirmed by the sequenced 16S rDNA genes of all isolates (Hookoom and Puchooa 2013) (Table 6).

\section{Optimization of growth parameters for selected isolates}

Optimum growth conditions of selected bacterial isolates were determined with respect to $\mathrm{pH}$ and temperature (Figs. 1 and 2). To determine optimum $\mathrm{pH}$, isolates were grown in LB broth adjusted at different $\mathrm{pH}$ i.e., 6, 7, 8, 9 and 10 and their absorbance was measured at $540 \mathrm{~nm}$ after $8 \mathrm{hr}$ of incubation @ $100 \mathrm{rpm}$. All the selected isolates showed maximum growth at $\mathrm{pH}$ 9. Out of four 
selected isolates, HM 3 showed fastest growth and HM 15 showed slowest growth whereas HM 2 and HM 16 showed comparable growth at $\mathrm{pH}$ 9. In vitro compatibility analysis by spot plate inoculation revealed HM 2 and HM 16 to be compatible with each other. Hussein et al., (2003) examined the effect of $\mathrm{pH}$ on growth of $\mathrm{Ni}$ and $\mathrm{Cr}$ resistant four selected strains and found that optimum $\mathrm{pH}$ for strain 9 and 12 was 5.5. Whereas, strains 2 and 16 have corresponding optimum $\mathrm{pH}$ close to 6 .

To determine optimum temperature, selected isolates were grown in LB broth at different incubating temperatures i.e $25^{\circ} \mathrm{C}, 35^{\circ} \mathrm{C}, 40^{\circ} \mathrm{C}$, $45^{\circ} \mathrm{C}$ and $50^{\circ} \mathrm{C}$ absorbance was measured at $540 \mathrm{~nm}$ after 8 hour of incubation @ $100 \mathrm{rpm}$. All isolates showed maximum growth at $40^{\circ} \mathrm{C}$.

The present study revealed the capacity of four (HM 2, HM 3, HM 15 and HM 16) heavy metal tolerant bacterial isolates, from effluents, to tolerate and grow at different concentrations (10-120 ppm) of five heavy metals viz. As, $\mathrm{Cr}, \mathrm{Pb}, \mathrm{Ni}$ and $\mathrm{W}$ but were sensitive to $\mathrm{Hg}$. On the basis of biochemical characterization HM 3 and HM 16 were more closely related to genera Enterobacter.

Whereas, HM 2 was found to belong to genera Klebsiella. Further, optimization of growth conditions of selected bacterial isolates with respect to $\mathrm{pH}$ and temperature showed maximum growth at $\mathrm{pH} 9$ and temperature $40^{\circ} \mathrm{C}$. Out of four selected isolates, HM 3 showed fastest growth and HM 15 showed slowest growth, whereas HM 2 and HM 16 showed comparable growth at $\mathrm{pH} 9$ with in vitro compatibility and were selected as potent candidate for consortium. This study elucidated the potential of resident microbes of effluents/sludge for heavy metal removal, as these bacterial species were well acclimatized to the ecology of metal contaminated aquifers.

\section{References}

Aksu, Z., Biosorption of heavy metal by microalgae in batch and continuous systems. Springer, 99: 37-53 1998.

Alam, M. Z., Ahmad, S. and Malik, A. Prevalence of heavy metal resistance in bacteria isolated from tannery effluents and affected soil. Environmental Monitoring and Assessment, 178: 281912011.

Alloway, B. J., Soil processes and the behavior of heavy metals. pp. 11-37. In: Heavy metals in soils. Alloway, B. (Ed). Chapman and Hall, New York 1995.

Anonymous, 2010. Technical EIA Guidance Manual for CETPs. By the Ministry of Environment and Forests (MoEFs). Government of India.

APHA, 2001. Standard methods for the examination of water and wastewater. $20^{\text {th }}$ edition Washington D.C: American Public Health Association.

Claus, D., and Berkeley, R. C. W. Endosporeforming Gram positive rods and cocci: Bacillus. Bergey's manual of systematic bacteriology, 2: 2-8 1986.

Doenmez, G., and Aksu, Z. The effect of copper (II) ions on the growth and bioaccumulation properties of some yeasts 35: 135-42 1999

Ellis, R. J., Morgan, P. and Weightman, A. J. Cultivation dependent and -independent approaches for determining bacterial diversity in heavy-metal-contaminated soil. Applied Environmental Microbiology, 69: 3223-30 2003

Ewan, K. B., and Pamphlett, R. Increased inorganic mercury in spinal motor neurons following chelating agents. Neurotoxicology, 17: 343-49 1996.

Filali, B. K., Taoufik, J. Z., Dzairi, Y., Talbi, F. Z. and Blaghen, M. Waste water bacteria resistant to heavy metal and antibiotics. Current Microbiology, 41: 151-56 2000. 
Giller, K. E., Witter, E. and McGrath, S. P. Toxicity of heavy metals to microorganisms and microbial processes in agricultural soils: A review. Soil Biology and Biochemistry, 30: 1389-1414 1998.

Gunaseelan, C., and Ruban, P. Heavy metal resistance bacterium isolated from Krishna Godavari basin, Bay of Bengal. International Journal of Environmental Sciences, 1: 1856-64 2011.

Haq, R., and Shakoori, A. R. Microorganisms resistant to heavy metals and toxic chemicals as indicators of environmental pollution and their use in bioremediation. Folia Biology, 48: 143472000

Hookoom, M., and Puchooa, D. Isolation and identification of heavy metals tolerant bacteria from industrial and agricultural areas in Mauritius. Current Research in Microbiology and Biotechnology, 1(3): 119-23 2013.

Hussein, H., Moawad, H. and Farag, S. Isolation and characterization of Pseudomonas resistant to heavy metal contaminants. Arabian Journal of Biotechnology, 7:13-22 2003.

Jun-xia, Y., TONG, Mi., Xiao-mei, S. and Bu-hai, L. I. Biomass grafted with polyamic acid for enhancement of cadmium (II) and lead (II) biosorption. Journal of Biochemistry and Engineering, 33(2): 126-33 2007.

Kamika, I., and Momba, M. N. B. Assessing the resistance and bioremediation ability of selected bacterial and protozoan species to heavy metals in metal-rich industrial wastewater. $B M C$ Microbiology, 13: 28-34 2013.

Kavamura, V. N., and Esposito, E. Biotechnological strategies applied to the decontamination of soils polluted with heavy metals. Biotechnology Advances, 28: 61-69 2010.

Khan, S., Cao, Q., Zheng, Y. M., Huang, Y.
Z. and Zhu, Y. G. Health risks of heavy metals in contaminated soils and food crops irrigated with wastewater in Beijing, China. Environmental Pollution, 152: 686-92 2008.

Kinare, P., and Shingadia, H. Screening of heavy metal resistant bacteria from Nale Lake of Vasai Taluka of Maharashtra. International Journal of Life Sciences, 2(2): 139-42 2014.

Kongtae, Ra., Eun-Soo, Kim, Kyung-Tae, Kim, Joung-Keun, Kim. Assessment of heavy metal contamination and its ecological risk in the surface sediments along the coast of Korea. Journal of Coastal Research, 65: 105-10 2013.

Lasat, M. M., Phytoextraction of toxic metals: a review of biological mechanisms. Journal of Environmental Quality, 31: 109-20 2002.

Menn, F. M., Easter, J. P. and Sayler, G. S. 2008. Genetically Engineered Microorganisms and Bioremediation. In: Biotechnology: Environmental Processes II 2008; 11b, Second Edition (eds Rehm HJ and Reed G), Wiley$\mathrm{VCH}$ Verlag GmbH, Weinheim, Germany. doi:10.1002/9783527620951.ch21.

Moore, J. W., Inorganic contaminants of surface water residuals and monitoring priorities. New York: Springer-Verlag. p. 178-210 1990 .

Roane, T. M., and Pepper, I. L. Microorganisms and metal pollution, in Environmental Microbiology, Edited by Maier R. M. Pepper I. L. and Gerba. C B (Academic Press, London, NW1 7BY.UK), 55, p403-423 2000.

Santona, L., Castaldi, P. and Melis, P. Evaluation of the interaction mechanisms between redmuds and heavy metals. Journal of Hazardous Material, 136: 324-29 2006.

Shakoori, A. R., and Muneer, B. Copper resistant bacteria from industrial 
effluents and their role in remediation of heavy metals in wastewater. Folia Micro-biological, 47: 43-50 2002.

Thacker, U., and Madamwar, D. Reduction of toxic chromium and partial localization of chromium reductase activity in bacterial isolate DM1. World Journal of Microbiology and Biotechnology, 21: 891-99 2005.

Thompson, M., and Walsh, J. N. 'Handbook of inductively coupled plasma spectrometry', Blackie Pp. 3161989.

Toroglu, S., and Dincer, S. Heavy metal resistances of Enterobacteriaceae from Aksu River (Turkey) polluted with different sources. Asian Journal of Chemistry, 21(1): 411-20 2009.
Verma, T., Srinath, T., Gadpayle, R. U., Ramteke, P. W., Hans, R. K. and Garg, S. K. Chromate tolerant bacteria isolated from tannery effluent. Bioresource Technology, 78: 31-35 2001.

Volesky, B., 1990. Biosorption of heavy metals. P.408, Boca Raton, FL: CRC Press Inc, ISBN 0-84934917-6

Waisberg, M., Joseph, P., Hale, B. and Beyersmann, D. Molecular mechanism of cadmium carcinogenesis. Toxicology, 192: 95-117 2003.

Wang, J.L., and Chen, C. Biosorption of heavy metals by Saccharomyces cerevisiae: a review. Biotechnology Advances, 24: 427-51 2006.

\section{How to cite this article:}

Gaganpreet Kaur, Priya Katyal and Dhanwinder Singh. 2017. Physico-Chemical and Microbiological Profile of Effluents from Common Effluent Treatment Plants (CETPs). Int.J.Curr.Microbiol.App.Sci. 6(9): 1403-1413. doi: https://doi.org/10.20546/ijcmas.2017.609.170 